University of Warwick institutional repository: http://go.warwick.ac.uk/wrap

This paper is made available online in accordance with

publisher policies. Please scroll down to view the document

itself. Please refer to the repository record for this item and our

policy information available from the repository home page for

further information.

To see the final version of this paper please visit the publisher's website. access to the published version may require a subscription.

Author(s): David Hardiman

Article Title: Knowledge of the Bhils and their Systems of Healing

Year of publication: 2006 


\section{Knowledge of the Bhils and their Systems of Healing}

\section{David Hardiman}

(Published in The Indian Historical Review, Vol. 33, No. 1, January 2006, pp.202-24)

In this essay, I shall examine how the Bhils of the border region between the present states of Rajasthan and Gujarat understood and treated ill health and disease in the late nineteenth century. Before I do this, however, I would like to say a few words about the methodological problems involved in reconstructing a social and medical history of a subaltern community living in a hilly tract that even today is not easy of access. The problem lies in the sources that are the most part available to us, namely writings by colonial officials and Christian missionaries whose understanding of these people was strongly coloured by their prejudices. Is it - we may ask - possible to utilise sources that are so tainted? I shall start by examining how the British regarded such people during the nineteenth century.

According to the Italian philosopher Benetto Croce (1886-1952), European thought since the time of the Enlightenment has made a distinction between those humans who were considered to be a part of 'history' and those who belonged to the 'inferior reality' of nature. The latter were:

...men only zoologically, they are to be dominated. They may be tamed and trained; when this proves impossible, they may be allowed to live on at the fringes of civilization, without being the object of any of those cruelties that must be avoided against any form of life, but being allowed as a race to die out like those [native] American races who shrank and died... when a civilization they could not withstand moved upon them. ${ }^{1}$

The British, when they conquered India, categorised in this manner a range of disparate communities scattered over the subcontinent, in the process creating for them a conceptual unity that they had never hitherto possessed. Those so singled out lived for the most part in the more inaccessible hill and forest tracts, and survived largely from hunting and gathering or rudimentary swidden agriculture. They were classed as 'aboriginals' or 'early tribes,' being characterised, amongst other things, by their 'clan'-based systems of kinship and their 'animistic' religious beliefs.

Sometimes, they were defined in terms of their habitat, as 'jungle tribes'

In India, the largest concentrations of people so classed were in the northeast.

Elsewhere, many were found in the central-eastern region, in what is now the state of Jharkhand and areas adjoining to it in Bengal, Orissa and Bastar, and in a belt of western India running over the four modern Indian states of Rajasthan, Gujarat, Madhya Pradesh and Maharashtra. ${ }^{2}$ In this latter area, there were considered to be two main types of such people - the so-called 'Kaliparaj' ('black people') who were found in the southern part of this belt, and the Bhils. The former were generally considered to be less warlike than the latter. In many cases, the Bhils had in the past

\footnotetext{
${ }^{1}$ Benedetto Croce, Filosofica e Storiografica, Bari: Laterza, 1949, 246; quoted and translated by Allesandro Portelli, The Death of Luigi Trastulli and Other Stories: Forms and Meanings in Oral History, Albany: State University of New York Press, 1991, ft.6, 293.

${ }^{2}$ A Social and Economic Atlas of India, New Delhi: Oxford University Press, 1987, 27.
} 
been organised in warlike kinship groups that had prevented outside rulers from extending their control over the mountains. The British had subjugated such Bhils with considerable difficulty - during the first half of the nineteenth century. Even afterwards, there were several revolts by them.

The British believed that they had a moral duty to 'civilise' these 'primitives'; freeing them from the state of nature in which they were mired and bringing them with the ambit of 'history.' They were encouraged to practice a more settled and intensive agriculture. In many cases, they were excluded from large tracts of forest that they had previously controlled, so that state foresters could exploit the timber wealth of the woodlands. ${ }^{3}$ Landlords, usurers and liquor dealers who were protected by the colonial and princely states ruthlessly exploited those who became settled. ${ }^{4}$ A large proportion of the area inhabited by such people in western India was ruled by Indian princes rather than directly by the British colonial state. Although nominally independent, these princes relied on British troops and British-run militias to maintain their control over their 'tribal' subjects. This was the case in Mewar and the adjoining princely states of Rajasthan and Gujarat - the region that provides the focus for this article.

James Tod, who served as Political Agent in Mewar from 1818 to 1822, stated that the 'primitive inhabitants' of that state were 'content to be called' Bhumiputra ('sons of the earth') or Vanaputra ('children of the forest'). He saw them as a culturally distinct group. ${ }^{5}$ He also described them as 'lawless' or 'wild tribes' who were being given too much freedom by the princely rulers:

Had the wild tribes been under the sole influence of British power, nothing would have been so simple as effectually, not only to control, but to conciliate and improve them; for it is a mortifying truth, that the more remote from civilization, the more tractable and easy to manage, more especially the Bhil. ${ }^{6}$

Unfortunately, according to Tod, 'these children of nature' were in these parts under the rule of oppressive feudal lords whose continuing misrule caused frequent revolts.

The most influential of the earlier colonial texts relating to the Bhils was John Malcolm's A Memoir of Central India, published in 1823. Malcolm, a general in the army of the East India Company, was sent in 1818 to establishing British control over Malwa and southern Rajasthan. He was Tod's superior. In this book, he started by pointing out that it was hard to know the Bhils, due to 'their dispersion over rugged mountains, their extreme ignorance and prejudices, and their repugnance to

\footnotetext{
${ }^{3}$ On this, see in particular David Hardiman, 'Power in the Forest: the Dangs, 1820-1940', in David Arnold and David Hardiman (eds.), Subaltern Studies VIII, New Delhi: Oxford University Press, 1994; and Ajay Skaria, 'Timber Conservancy, Desiccationism and Scientific Forestry: The Dangs 1840s1920s', in Richard Grove, Vinita Damodaran, Satpal Sangwan (eds.), Nature and the Orient: The Environmental History of South and Southeast Asia, New Delhi: Oxford University Press, 1998. ${ }^{4}$ On usurers see David Hardiman, Feeding the Baniya: Peasants and Usurers in Western India, New Delhi, Oxford University Press, 1996; on liquor dealers see David Hardiman, 'From Custom to Crime: The Politics of Drinking in Colonial South Gujarat', in Ranajit Guha (ed.), Subaltern Studies IV, New Delhi: Oxford University Press, 1985.

${ }^{5}$ James Tod, Annals and Antiquities of Rajasthan, edited by William Crooke, Vol. 2, London: Humphrey Milford, 1920, 651. The work was first published in two volumes of 1829 and 1832.

${ }^{6}$ Tod, Annals and Antiquities of Rajasthan, Vol.1, 586.
} 
confidential intercourse with all except their own tribe... ${ }^{7}$ Despite this, he attempted 'some conjectures regarding the origin and progress of the tribe...' They were, he said, 'a distinct race, insulated in their abodes, and separated by their habits, usages, and forms of worship, from the other tribes of India., ${ }^{,}$In the remote past they had been expelled to the woods and hill after they had slaughtered the favourite bull of the god Mahadev - a dire transgression in Hindu society. They became Nishada, or outcastes. From that time on 'they have since dwelt, subsisting partly on their industry, but more on the plunder of the rich landholders in their vicinity. ${ }^{9}$ Although some had settled down in the plains regions as peaceful cultivators, the 'wild, or mountain Bheel,' continued to prefer 'savage freedom and indolence to submission and industry, [and] have continued to subsist by plunder. ${ }^{10}$

The plundering or wild Bheels, who reside among the hills, are a diminutive and wretched-looking race, whose appearance shews [sic] the poverty of their food; but they are nevertheless active and capable of great fatigue. They are professed robbers and thieves, armed with bows and arrows: they lie in wait for the weak and unprotected, while they flee from the strong. Ignorant and superstitious to a degree, they are devoted to their Turwees [chieftains], whose command is a law which they implicitly obey. The men, and still more the women, have their intellect formed by their condition; they are quick, have a kind of instinctive sense of danger, and are full of art and evasion. To kill another when their Turwee desires, or to suffer death themselves, appears to them a matter of indifference. The whole race are illiterate, and they are, without exception, fond of tobacco and liquor to excess. Their quarrels begin and end in drunken bouts... ${ }^{11}$

In Malcolm's account, the 'wild, or mountain' Bhils were characterised by their animal-like or feral traits, as seen in their undomesticated habitat, their rudimentary and predatory forms of subsistence, their instinctive rather than considered reactions, their proclivity towards excess rather than a civilised moderation, their unreflective obedience to the leader of the pack, their pre-religious amorality, their superstition, and their complete lack of learning. In every way, they were the mirror image of the civilised Englishman, being a people that more than any other had to be disciplined and civilised.

The missionaries who entered these territories later in the nineteenth century took such accounts as their guide. Thus, when the journal of the Church Missionary Society, the Intelligencer, published an article on the Bhils in 1882, it reproduced large swathes of Malcolm's text almost verbatim. The unstated assumption was that as the Bhils existed in a state of nature, their condition would have remained largely unchanged since 1820. They were classed as 'non-Aryans,' that is, as an aboriginal race that was distinct from the later Aryan invaders who had driven then into the

\footnotetext{
${ }^{7}$ John Malcolm, A Memoir of Central India, Including Malwa, and Adjoining Provinces, with the History, and Copious Illustrations, of the Past and Present Condition of that Country, Vol. 1, 1823, republished New Delhi: Sagar Publications 1970, 516-17.

${ }^{8}$ Malcolm, A Memoir of Central India, Vol. 1, 517-18.

${ }^{9}$ Malcolm, A Memoir of Central India, Vol. 1, 519.

${ }^{10}$ Malcolm, A Memoir of Central India, Vol. 1, 521.

${ }^{11}$ Malcolm, A Memoir of Central India, Vol. 2, 179-80.
} 
hills. ${ }^{12}$ Even when the missionaries later provided more detailed descriptions of the Bhils that were based on their own enquiries and observations, they remained confined within these mental parameters. The Reverend C.S. Thompson thus argued in an article of 1897 that the Bhils among whom he worked were in fact of mixed race, being descended in part from a pre-Aryan 'primitive people' of Central India, as well as from Mongolian tribes that entered India before 1500 B.C., and also from 'predatory Rajput chiefs' who had seized and married Bhil women after about 1000 A.D. In this way he sought to explain the fact that he had observed many physical gradations among them, 'from the man who is almost a pure Rajput in complexion and physique to the black and stunted inhabitant of the forest. Moreover, here and there may be noticed features which are distinctly Mongolian. There can, therefore, hardly be any doubt that the Bheels unite in themselves a strain of these aboriginal, Mongolian, and Rajput stocks.' ${ }^{13}$ It is clear from this passage that Thompson was unable to transcend a discourse of racial identity that was both fanciful and insidious.

A feature of this discourse was that it conferred a homogenised identity on peoples who might be scattered over large regions, countries or even continents. Thus, a variety of groups that lived in hills and forests were categorised as 'primitive tribes' who were supposed to share similar global characteristics. Viewed through such a lens, Bhils might be seen to possess certain 'negroid' characteristics. An anonymous British traveller in western India in the early 1820s thus described the Bhils as 'a short, thick-set people, with hideous countenances, flat noses, and thick lips, but far less handsome and finely formed men than the Africans; ...they look stupid.... Their women are even more hideous than the men. ${ }^{14}$ Rudyard Kipling made a similar sort of comparison over sixty years later on a visit to Mewar State, where he had observed some Bhils whose speech, he claimed, 'seems to possess some variant of the Zulu click, which gives it a weird and unearthly character.' ${ }^{15}$ In fact, the language of the Mewari Bhils was very close to the neighbouring Gujarati, as was discovered by the missionaries when they began to translate the Gospel for their benefit. Such descriptions continued into the twentieth century. Writing in 1926, a missionary stated of the Bhils of Mewar:

The difference in race is visible at a glance. ...they are a very dark-skinned people. Instead of the clear-cut, handsome profile of the Aryan, they have blunt features. The nose is broad, the lips often thick as those of a negro, and the hair is worn long. Unlike that of the negro, it is straight or wavy but not curled. ${ }^{, 16}$

The Bhils - who were found throughout a belt of hills and mountains in western India that stretched over three hundred kilometres from north to south and in places a hundred and fifty kilometres from east to west - were all lumped together as one

\footnotetext{
12 'Some Account of the Bheels,' Intelligencer, October 1882, 585-91.

${ }^{13}$ C.S. Thompson, 'The Bheels,' The Church Missionary Gleaner, October 1897, 148.

${ }^{14}$ Sketches of India, $4^{\text {th }}$ edition, 1826, 257-8. Quoted in David Arnold, 'Race, Place and Bodily

Difference in Early Nineteenth Century India,' Historical Research, 77, 196, 2004, 266.

${ }^{15}$ Rudyard Kipling, 'Letters of Marque, Nov-Dec 1887,' reprinted in Kipling, From Sea to Sea and Other Sketches: Letters of Travel, Vol. 1, London: Macmillan, 1926, 57.

${ }^{16}$ George Carstairs, Shepherd of Udaipur and the Land he Loved, London: Hodder and Stroughton, 1926, 227.
} 
unique ethnic and cultural category. It was assumed that 'the Bhil' everywhere had practically identical traits, so that an observation of a Bhil in one area could be taken to apply to all Bhils everywhere. Thus, what John Malcolm had to say about the Bhils of Malwa around 1820 were taken to apply to Bhils everywhere and at all times. In many cases, a stereotypical model of 'primitivism' appears to have been the starting point for a description; with observations being recorded only when they accorded with it. This appears to have been the case with one sweeping generalisation made about the Bhils by the author of the Rajputana Gazetteer of 1879: 'They are a dirty race. The men wear their hair long, and hanging in uncombed masses over their shoulders. The women are small and ugly... ${ }^{17}$ Many counter-observations might have been made - but they were not - as they would have opposed the pre-conceived stereotype.

Given that this was the case, we are presented with the problem with which I started. With our knowledge of these people in the past coming from such tainted sources, is it possible for us to know anything about them that is more than an objectionable caricature? Gayatri Chakravorty Spivak has raised the question as to what extent, if any, the outside observer can represent the subaltern. ${ }^{18}$ Given the chasm that exists between those who inhabit a space of privilege and those who do not, any representation runs the risk of being an exercise in bad faith. Too often, the outsider inflicts her or his beliefs on the subaltern, whether these are of a racist, Christian, conservative, nationalist, socialist, feminist, environmentalist or any other bent. In such a situation, she feels, 'the subaltern cannot speak. ${ }^{19}$ Despite this, she goes on to argue that the intellectual with a moral commitment to the poor and oppressed may communicate across this divide, so long as she or he steers clear of all 'missionary claims' - that is avoids any assertion that the subaltern is endorsing any pre-conceived ideological position. ${ }^{20}$ What is required above all is moral sympathy and empathy. This I would endorse entirely.

The other main principle that I believe that we should follow is to be as specific and as historical as we can in our writing. The detailed description that is rooted in a particular time and place is thus more likely to contain information that is of value. Ranajit Guha has distinguished between primary, secondary and tertiary levels of documentation of this sort. The primary type was created characteristically by colonial officials who were ruling an area or suppressing a revolt, as well as by those symbiotically related to them such as traders, missionaries and the indigenous elites. As a rule, they have the great advantage of being written close to the subject and soon after an event, in the process recording many elements that were later filtered out in the secondary and then tertiary levels of documentation. Such sources provide evidence that creates the conditions for a radically different reading that runs 'against the grain. ${ }^{21}$ In this respect, a detailed report by an official or missionary written soon after a visit to a specific Bhil village is likely to provide a more reliable

\footnotetext{
${ }^{17}$ The Rajputana Gazetteer, Vol.1, Calcutta, 1879, 117.

${ }^{18}$ Gayatri Chakravorty Spivak, A Critique of Postcolonial Reason: Toward a History of the Vanishing Present, Cambridge, Mass: Harvard University Press,.1999, 255 and 269. See also Gayatri Chakravorty Spivak, 'Can the Subaltern Speak?' in Cary Nelson and Lawrence Grossberg, Marxism and the Interpretation of Culture, Basingstoke: Macmillan, 1988.

${ }^{19}$ Spivak, Critique of Postcolonial Reason, 273.

${ }^{20}$ Spivak, Critique of Postcolonial Reason, 310.

${ }^{21}$ Ranajit Guha, 'The Prose of Counter-Insurgency,' in Ranajit Guha (ed.), Subaltern Studies II, New Delhi: Oxford University Press, 1983, 3-4.
} 
reflection of their way of life and being than a broad generalisation by the compiler of a general ethnography or a gazetteer. Bearing this in mind, it is best to begin by locating our observations within a carefully defined and finite area, such as the Bhil tracts of Mewar and Dungapur in Rajasthan and the immediately adjoining states of Idar and Pol - that lay in Gujarat and were under the British political agency of Mahikantha - rather than a vague 'land of the Bhils' that spans whole regions and provinces. Details that conflict with the stereotypes should be considered and analysed carefully. The historically specific detail should be valued over the broad and ahistorical statement. From this base, we may then go on to make comparative observations drawn from carefully defined subaltern groups elsewhere.

Adopting this approach, I shall now examine the issue of how the Bhils of this area understood disease, and how they set about treating ill health in the latter part of the nineteenth century. To do this, I have sought out documentation that is as 'primary' as possible in Ranajit Guha's sense; that is, documentation that was created in a stated context, locality and situation and which is rich in detail. Although it will inevitably give voice to the prejudices of the writer, the detail should be sufficient to allow us to distinguish its particular bias and go on to provide a reading 'against the grain.' My starting point is an article written by Dr. Thomas Hendley of the Indian Medical Service, who from 1871 served as an Assistant Surgeon at the small military hospital of the Mewar Bhil Corps at Kherwara. He was in daily contact with his Bhil patients, and he took an active interest in them and their way of life. He also talked at length with a local Thakor, or feudal overlord, called Gambhir Sing. Major Gunning, the Commandant of the Bhil Corps, read Hendley's first draft and added more details. The resulting 42-page account was published in $1875 .^{22}$ It examined many different aspects of Bhil life, not just the medical. It is however the latter aspect that I intend to focus on here.

Hendley - with his medical training - considered himself a man of science, and during his long career in India he was to publish many scholarly articles based on his observations of the people and the country. In 1875 - still a junior doctor - he was in the vanguard of a new scientific racism that held that racial characteristics could be measured physically. This would, it was held, allow a history to be constructed of the movements and migrations of different races throughout the world, so that maps could be made showing their contemporary geographical locations. His posting to Kherwara provided him with an excellent opportunity to carry out what he called an 'ethnology' of the Bhils that was based on observations of their physical characteristics and measurements. He did this in 1874, subjecting 129 soldiers of the corps to his measuring tape, recording their height, the length of various limbs and parts of limbs, body proportions and heads dimensions. He concluded that they were 'a small-handed race,' with small chest and pelvis. The head measurements revealed that 'the Bhil skull is but slightly dolicho-cephalic, very different from the long thin walled crania of the pure Hindu.' He set out his observations of their physical appearance - their dark skin, straight black hair, foreheads that were 'rather more

\footnotetext{
${ }^{22}$ T.H. Hendley, 'An Account of the Maiwar Bhils,' Journal of the Asiatic Society of Bengal, 44 pt. 1, 4, 1875, 347-88.
} 
square than amongst Hindus,' 'nose slightly retroussé, broad, clubbed at the tip, and rather more varied than the dead level organ of the Hindu,' 'mouths large, lips thick, inexpressive, sensual...', 'expression amiable, but timid,' 'the dilated large nostrils, the moveable and prominent ear are very suggestive of distrust.' Teeth were large and horselike, adapted to chewing their staple food of coarse maize. He was not sure that his measurements provided a 'certain proof' that the Hindu and Bhil races were distinct, though he believed that they were, the Bhils most likely being descendents of the ancient inhabitants of India, the Dasyas, who were described in the Vedas as 'goat-nosed, the noseless, the black-skinned... ${ }^{23}$ For all its seeming scientific rigour, this exercise dripped with moral judgement.

Despite this, the detail in other parts of the article is sufficient to allow us to go beyond such racist stereotypes. The 'ethnology' that is so objectionable to presentday sensibilities was set out in the article only towards the end, with a range of far less value-loaded descriptions of the Bhils of this area preceding it. It is these that I shall look at, comparing them with other representations if necessary.

Hendley felt that in general: 'The Bhils are a healthy race.' For example, cholera, perhaps the most dreaded disease in nineteenth century India, was very rare among them. ${ }^{24}$ In common with many other medical men of that era, he appears to have believed that 'primitive' people were less subject to the ravages of illness than the more 'civilised.' Michel Foucault has commented on this belief, quoting the French physician Tissot, who just before the Revolution stated that: 'Before the advent of civilisation, people had only the simplest, most necessary diseases. Peasants and workers still remain close to the basic nosological table; the simplicity of their lives allows it to show through in its reasonable order: they have none of those variable, complex, intermingled nervous ills, but down-to-earth apoplexies, or uncomplicated attacks of mania. ${ }^{25}$ It was believed that as people improved their condition of life, and as the social network tightened its grip around individuals, 'health seems to diminish by degrees.' Diseases become diversified and combined with one another. As Tissot had stated in an earlier work: 'their number is already great in the superior order of the bourgeoisie;... it is as great as possible in people of quality. ${ }^{26}$ Writing in such a vein a century later, Hendley said of the Bhils: 'Insanity is uncommon, perhaps unknown as we should expect in a savage race with the mind rude and uncultivated and little to excite it. I have never seen a case of mania, and only one or two of dementia in old age. ${ }^{27}$

\footnotetext{
${ }^{23}$ Hendley, 'Account of the Maiwar Bhils,' 367-68.

${ }^{24}$ Cholera was prevalent in the area - for example 9 cases were reported at the annual fair at Shamlaji, in the heart of the Bhil country, in 1889, of which 5 proved fatal. This outbreak does not appear to have spread beyond this town. Mahi Kantha Annual Administration Report, 1889-90, Gujarat State Archives, Vadodara Branch, Crown Representative Records, Daftar 50, F 37, Colonel H.L. Nutt, Acting Political Agent, Mahi Kantha, to Pol. Dept. Govt. of Bombay, Sadra 21 and 23 July 1890, 21. In 1900, however, there was an epidemic of cholera at a time of famine that killed large numbers of the Bhils of this area. See Arthur Outram to Durrant, Kherwara, 21 May 1900, Church Missionary Society Records, University of Birmingham, G2 I 60 1900, doc. 304.

${ }^{25}$ Tissot, Traité des nerfs et leurs maladies, Vol. II, Paris: 1778-80, 432-44, quoted in Foucault, the Birth of the Clinic: An Archaeology of Medical Perception, London: Routledge, 1991,16.

${ }^{26}$ Tissot, Essai sur la santé des gens du monde, Lausanne: 1770, 8-12, quoted in Foucault, Birth of the Clinic, 17.

${ }^{27}$ Hendley, ‘Account of the Maiwar Bhils’, 363.
} 
One disease that was a killer for the Bhils, and which was as a result greatly feared by them, was smallpox. Hendley noted that they practised their own form of inoculation against this disease, and they preferred this to western-style vaccination. ${ }^{28}$ In another account written later, Hendley provided more detail of their inoculation technique. They dipped a grain of dust into the pustule of a smallpox patient and then inserted this into the skin of a healthy person with the help of a needle. While doing so they invoked the smallpox goddess. ${ }^{29}$ As was common throughout India, the Bhils believed that in cases of smallpox the body of the sufferer was possessed by a goddess and thus made feverish. Helen Lambert has describes how villagers in Rajasthan were still in the 1980s holding communal ceremonies of worship that were designed to placate such goddesses and thus protect themselves from the disease. ${ }^{30}$ The invocation of the goddess by the Bhils during inoculation would seem to have had a similar aim.

Many suffered from guinea worm and skin disorders, two problems that were 'mainly due to the filthiness of the people, whose legs often remain coated for days with mud.' Hendley had already carried out research on guinea worm infestation among the Bhils of the MBC that had been published in The Indian Medical Gazette in 1872. This was a problem that affected the Bhils in particular - the non-Bhils of Kherwara town rarely suffered from it. He believed that the worms entered into the skin of the Bhils as they were bathing in or wading through dirty pools of water. People did not die of it, but it caused great debilitation. ${ }^{31}$ Dr Mullen, Hendley's predecessor as surgeon to the MBC, had reported that venereal disease was unknown among the Bhils, and Hendley agreed with him in this, and it provided proof of their general sexual restraint. Goitre, also, was never seen.

Hendley's list of serious or widespread maladies is only partial, omitting several that appear in other sources. For example, the missionary doctor James Shepherd reported that Bhils treated at his clinic in Udaipur in the late nineteenth century commonly suffered from malaria, dysentery, rheumatism, and 'cough' or phthisis (e.g. tuberculosis). He was surprised by the latter, as - in his view - the air in the hills had a bracing quality that should have countered the disease. ${ }^{32}$ Dr. Jane Birkett, a medical missionary who began medical work amongst the Bhils of this area in 1900, noted that:

Malarial fever with immense enlargement of the spleen is the commonest ailment, and it is quite pitiful to see the extent of anaemia and debility from which the whole population suffers in consequence. Tiny babies, only a few weeks old often had spleens the size of the palm of my hand, beyond their

\footnotetext{
${ }^{28}$ Hendley, 'Account of the Maiwar Bhils,' 362.

${ }^{29}$ Hendley, General Medical History of Rajputana, Calcutta: Government Press 1900, 148.

${ }^{30}$ Helen Lambert, 'The Cultural Logic of Indian Medicine: Prognosis and Etiology in Rajasthan Popular Therapeutics,’ Social Science and Medicine 34, 10, 1992, 1071. See also David Arnold, Colonizing the Body: State Medicine and Epidemic Disease in Nineteenth-Century India, Berkeley: California University Press, 1993, 121-25. Arnold examines indigenous forms of inoculation on 12533.

${ }^{31}$ T.H. Hendley, 'Filaria Dracunculus or Medinensis at Kherwarrah,' The Indian Medical Gazette, A Monthly Record of Medicine, Surgery, Obstetrics, Jurisprudence and the Collateral Sciences; and of General Medical Intelligence, Indian and European, Vol. 7, 1872, 59-60.

${ }^{32}$ Carstairs, Shepherd of Udaipur, 239.
} 
ribs; and adults often present a hard smooth tumour which passes from the L. ribs to well over the right of the middle line, and even into the R. iliac fosa.

After malaria, skin and eye affections were the chief complaints. Ringworm was the most widespread skin problem, and granular lids with their sequelae the commonest eye trouble. Guinea worm was a major problem during the rainy season, and sufferers often had four or five absesses on one leg. There was also much phthisis and rheumatism. There were fairly frequent cases of acute pluro-pneumonia, which was known as 'the Gujarati sickness,' which suggests that it was considered to have been brought from outside the Bhil region in recent times. It was particularly dreaded as it normally led to death. ${ }^{33}$ From all this, it is clear that the Bhils suffered from many illnesses, several of which were associated with poverty and poor living conditions.

Moving on to forms of treatment, Hendley described a variety of herbal remedies used by the Bhils, such as the roots of certain plants or leaves of trees. Thus, a small shrub called bhut bhangra was dried and powdered and used to treat open wounds. If a purulent wound was caused by the bite of a tiger, a cure was obtained from the kajera tree. Sat or Bara Mula was used in cases of fever accompanied with dry swollen tongue and bad smell, and as a mouthwash. Hendley lists eight such herbal remedies, ${ }^{34}$ but there must have been many more. Hendley also stated that the 'priests are the chief physicians, although most old men are supposed to know something about medicine. ${ }^{35}$ By this, he presumably meant the 'medicine' that was derived locally from herbs and trees.

He mentioned another common method of treatment: 'The remedy for everything is the actual cautery; few adults, few children, and even animals are without scars. ${ }^{36}$ He does not elaborate on this, but later reports by medical missionaries back this observation up. Dr Jane Birkett commented in 1901: 'Amongst the Bhils fire seems to be the great therapeutic agent. Most of them are marked with an arrow-head in the pit of the stomach; this was done to cure cholera. Scars from burns are also on their legs and arms. ${ }^{37}$ Such cauterization was not peculiar to the Bhils, it was used throughout the region at that time, including amongst the caste Hindus of the plains. For Bhils, the rationale for this practice was that it drove away the malign spirit that was causing the problem, as such spirits feared fire. ${ }^{38}$

Hendley also says something about childbirth practices, noting that women in labour were as a rule aided only by their women friends. They were kept in a warm hut, 'and even in cases of haemorrhage, [they] apply warm cloths, and administer hot-spiced drinks.' If there were difficulties, a wise woman of another caste might be called, or the women merely invoked the mother goddess. Cross births were rare, and were either left to the goddess, or the foetus was hooked or cut up in accordance with the

\footnotetext{
33 Jane L.J. Birkett, 'Report of Medical Work in the Bhil Mission for 1901,' Church Missionary Society Records, University of Birmingham, G 2 I 6/0 1902, doc. 75.

${ }^{34}$ Hendley, 'Account of the Maiwar Bhils,' 363.

${ }^{35}$ Hendley, 'Account of the Maiwar Bhils,' 363.

${ }^{36}$ Hendley, 'Account of the Maiwar Bhils,' 362.

${ }^{37}$ Mrs A.I.Birkett, 'Bhil Mission', Mercy and Truth, 5, 50, 1901, 45.

${ }^{38}$ This was stated by J.C. Brooke, Commandant of the Mewar Bhil Corps in 1851, Brooke to G.S.P.Lawrence, Political Agent Mewar, 7 April 1851, National Archives of India, Foreign Department [hereafter NAI, FD], 16 February 1853, 121-23 FC.
} 
advice of the most knowing person. This was however the practice amongst Hindus as well. The baby was suckled for two or three years. ${ }^{39}$

Hendley observed that the Bhils believed that some people - mainly women - had the ability to cause sickness, misfortune or death. It was considered that they were in touch with malevolent spirits, such as bhuts and churails (male and female departed spirits), and they could cause them to attack a person through their malign glance. They were known as dakran (Hindi - dakini), translated normally by the British, including Hendley, as 'witch.' Many Bhils wore charms or amulets on their right forearms or - with women especially - on their heads to keep such spirits at bay. The charms consisting generally of a piece of blue string with seven knots that were tied by an exorcist while he chanted incantations. ${ }^{40}$

What Hendley fails to mention, but which had come out in an earlier report by a Commandant of the Bhil Corps, was that women who possessed such powers were also valued for the protection that they were believed to be able to provide for their own families. 'To protect themselves from the consequences of being bewitched they will not marry into a family in which there is not a reputed witch to defend them from others of her species, and these again, as in England in former days, do everything to encourage, for the sake of the influence thereby acquired, this belief in their supernatural power. ${ }^{41}$ The dakran was thus a significant figure within a village politics that revolved around rivalries between families. In serious cases of alleged witchcraft, such as a sudden and unexpected death, the attribute could have tragic consequences for the woman concerned.

In such cases, an exorcist - called a bhopa - was employed to name the witch responsible.

Any one who is willing and has a grievance, sickness, or otherwise, has only to bribe a witch-finder sufficiently to obtain a victim, generally the wife or relative of an enemy, who is at once swung, head downwards, on a tree, where she is tortured by applications of red pepper to her eyes, nostrils, \&c. Not twenty years ago, during the rains, a woman was swung in this way in the presence of British officers, who were unable to rescue her, as an impassable river lay between them. Should the unlucky woman escape death, she is turned out of the village, or, perhaps, the bhopa finds out under the influence of another douceur, that he was mistaken. ${ }^{42}$

Although Hendley's language is laced with contempt for the bhopa, they were highly regarded within Bhil society. Those who enjoyed a wide reputation for their skill and integrity would sometimes be called from a great distance to intervene in the most intractable cases. It was considered wrong to take action against a witch without a bhopa passing judgement first. In 1864, for example, a Bhil of Semlia village in Idar State suffered a wound that continued to weep blood even after being sewn up. The man's brother believed that a woman called Rupa was responsible, and he killed her

\footnotetext{
${ }^{39}$ Hendley, 'Account of the Maiwar Bhils,' 352.

${ }^{40}$ Hendley, 'Account of the Maiwar Bhils,' 351-2.

${ }^{41}$ J.C. Brooke to G.S.P.Lawrence, Political Agent Mewar, 7 April 1851, NAI, FD, 16 February 1853, 121-23 FC.

${ }^{42}$ Hendley, 'Account of the Maiwar Bhils,' 351.
} 
with his sword. The local official stated this was seen as reprehensible as: 'If the woman was a witch the Bhopas ought to have been sent for to establish the fact. ${ }^{43}$

A particularly malign case of witchcraft was considered a general social threat, and once a witch had been named, everyone was required to support the action against her, even if they were her relatives. Thus, when in 1850 a Bhil woman died in Bhimpur village of Idar State, it was believed that Rakhi, the wife of the dead woman's husband's half-brother, had cursed her. She was seized, taken to the cremation ground, and burnt alive on the funeral pyre. The Political Agent in Mahikantha commented:

The whole village appears to have been assembled on this occasion, a few of the nearer relatives of the victim of this burst of superstition were present but even they seem to have joined in the belief that she was a witch and did nothing to save her. ${ }^{44}$

He went on to note that so dangerous were such witches considered that their killing was seen 'merely as an act of self-defence not only reasonable but almost as necessary.' Nonetheless, it seems that most of such women escaped with their lives, either through a confession leading to some punishment for her and her family, or through her exile from the village. Writing in 1851, J.C. Brooke, Commandant of the Mewar Bhil Corps, estimated that there were about a hundred such cases each year in the area under his jurisdiction, of which about one in ten led to the death of the accused woman. ${ }^{45}$

The Bhils looked to their rulers to take a lead in preventing witchcraft, and up until the middle years of the nineteenth century they largely obliged. In 1842, the British Resident reported that witches were put to death in public in Udaipur City on the accession of Maharana Sarup Singh. ${ }^{46}$ Local Thakors acted in a similar manner. For example, the Political Agent for Mahikantha recounted how in 1850 the Thakor of Gher was asked by the people of Chapra to come urgently to their village to tackle a case of suspected witchcraft, as the victim was dying. The Thakor went, and a woman of the potter caste who was considered have cast the spell was seized and brought to him. He told the other potters that if they tried to intervene to save her, he would seize their property. She was then put to death, after which the Thakor ordered some Bhils to take away her body and bury it. ${ }^{47}$ The health of society was thus considered a collective concern so far as witchcraft was concerned. Witches were seen to threaten social stability from within, and it was considered a duty for those with power to counter their sorcery. There was a clear connection between local power and the prevention of supposed sorcery. Weaker members of the society tended to be the ones accused, such as old women, widows, or, in a few cases, subordinate males. In cases of illness in which witchcraft was not suspected, no

\footnotetext{
${ }^{43}$ Thanedar of Poshina, 9 April 1864, Oriental and India Office Collection [hereafter OIOC], $\mathrm{R} / 2 / 700 / 39$.

${ }^{44}$ R. Wallace, Political Agent in Mahikantha, to Mallet, 3 September 1850, OIOC, R/2/700/39.

${ }^{45}$ Brooke to G.S.P.Lawrence, Political Agent Mewar, 7 April 1851, NAI, FD, 16 February 1853, 12123 FC.

${ }^{46}$ Hari Sen, 'Popular Protest in Mewar in the Late-Nineteenth and Early-Twentieth Centuries,' unpublished Ph.D. thesis, University of Delhi 1996, 120.

${ }^{47}$ R. Wallace to Malet, 4 September 1850, OIOC, R/2/700/39.
} 
collective response was considered necessary - individuals and families were left to treat the condition as they felt fit.

The British, after their conquest of India, had sought to outlaw the persecution of witches, a practice seen as barbaric. This ban was extended to the princely states of Rajasthan and Gujarat in the 1850s. ${ }^{48}$ When announcing the ban in the states of Mahikantha, the Political Agent, Major Whitelock issued a proclamation:

It is now hereby notified and declared that sorcery and enchantment have no real existence and are sheer prejudices and deceptions; and let it be clearly understood by all that the Almighty has not invested any human being with the supernatural power of causing the death of a fellow creature by the means of any such imaginary arts, and if any person shall profess to cause another bodily pain, or any injury to his person, family or property whatsoever, by pretended witchcraft, magic, or other such fraudulent practices, or if any person shall threaten to have recourse to witchcraft, or offer to remove fictitious evil-spirits for any one, and by such gross deceit shall receive, or shall obtain a promise of any gratuity, or remuneration in any shape whatsoever, that person will be punished for fraud, extortion and intimidation; and it is hereby further proclaimed that if any person or persons shall cause the death of another person under the false belief that he or she practised witchcraft or other delusive arts of any kind, then such person or persons will be tried for the crime of murder and dealt with accordingly. ${ }^{49}$

In Whitelock's view, belief that illness and misfortune could be caused by an evil force was not only irrational, but opposed also to true religion. In this, he gave voice to a belief that had emerged in Europe during the Enlightenment. An important thinker in this respect was Spinoza (1632-77), who had argued that many popular beliefs were delusions and superstitions - even when seemingly endorsed by the scriptures - and that those who were informed by the 'natural light of reason' had no use for them. God had created a good world, without inherent evil, and by abandoning the idea of evil, humans could free themselves from irrational fears. By the mid- $18^{\text {th }}$ century, mainstream Anglican theologians had, following such precepts, largely abandoned the concept of hell and its demonic forces, though some popular sects continued to believe in them. ${ }^{50}$ What Whitelock was reflecting was, in other words, a relatively recent form of theology particular to Europe. He was, moreover, not only asserting that it was a delusion to believe in witchcraft and evil agency, but that it was a notion that was characteristically deployed in a self-serving and 'fraudulent' manner. Anyone practising such 'fraud, extortion and intimidation' would be punished harshly under the law. Hendley had also made such an assumption when he wrote, as we have seen above, that the bhopa was 'bribed' to identify a witch, and that he might be made to change his opinion 'under the influence of another doceur.' 51

\footnotetext{
${ }^{48}$ Ajay Skaria, 'Women, Witchcraft and Gratuitous Violence in Colonial Western India', Past and Present, 155, 1997, 138.

${ }^{49}$ Zahir Nameli issued to the inhabitants of Mahi Kantha, 23 October 1856, OIOC, R/2/700/39.

${ }^{50}$ D.P. Walker, The Decline of Hell: Seventeenth-Century Discussions of Eternal Torment, Chicago: The University of Chicago Press, 1964, 7, 253-4 and 262-63; Bertrand Russell, History of Western Philosophy, London: George Allen and Unwin, 1967, 556.

${ }^{51}$ Hendley, 'Account of the Maiwar Bhils,' 351.
} 
Nowhere in this was there recognition that the bhopas were generally considered sincere and skilled exorcists who were able to use their powers to make contact with the spiritual world to detect the source of a malign force.

In a discussion of how historians have approached the question of medieval trials by ordeal for those who were seen as transgressors, Talal Asad has noted how they have tended to focus on what people believed, rather than:

...the power structure by which certain truths about transgressions were determined. Thus, we don't know what were the real thoughts and feelings of individuals who could at one time resort to the ordeal and who were later obliged to submit to the inquisitorial courts. But we do know that they were processed through very different political-legal-moral structures, subject to very different powers. Their options, their behaviour, their relationship to the personnel necessary for determining guilt or innocence were all very different. $^{, 52}$

In arguing as they did, colonial officers such as Whitelock and Hendley likewise focussed on belief rather than social structure, in the process failing to acknowledge the degree to which the notion of witchcraft was socially embedded and universally believed in as a matter of common sense. For example, even the unfortunate women so accused also believed in the reality of casting curses - their main plea being that they had either not - or had at least not intentionally - cast such a spell. In approaching the matter on the level of true and false consciousness, Whitelock and Hendley failed to appreciate that such an argument would carry no weight with those to whom it was addressed. Local holders of power took action against witches because they were convinced that they had a duty to preserve their society from malign supernatural forces. They strongly resented the new law, and the practice was driven underground rather than suppressed.

In dealing with the illnesses and misfortunes brought by malign supernatural forces, Hendley discusses only witchcraft. This was no doubt the most dramatic manifestation of the phenomenon, but probably not the most common. Singling out a particular person for blame caused inevitable controversy and poisoning of relations within a village, and it was only done in desperation or because of some ulterior political motive. As a rule, malign forces were countered through ritual sacrifices and the deployment of charms that had no particular human target. A missionary who worked in this area noted in 1906 that if an illness did not respond to herbal remedies, offerings of a chicken and some ghee and salt might be made at the tomb of an ancestor. $^{53}$ The Bhils bhopas often prescribed and performed such rituals, being paid generally in liquor, or in the meat from the sacrifice. The Bhils also believed that the Hindu mendicants who came to live in solitude in their hills and forests had similar powers. For example, when a Bhil women fell ill in 1843, her husband sought advice from one 'Gosain Nurbegur,' who said that he could provide a healing charm if liquor

\footnotetext{
52 Talal Asad, Genealogies of Religion: Discipline and Reasons of Power in Christianity and Islam, Baltimore, The John Hopkins University Press, 1993, ft.5, 91.

${ }^{53}$ A.H. Bull, 'Some Bhil Customs,'The Nagpur Diocesan Quarterly Magazine, January 1906, Christ Church Mission Press, Cawnpore, 41.
} 
was procured. ${ }^{54}$ Gosais were generally sadhus - that is mendicants who had renounced worldly life - of the Jogi or Nathapanthi sects. ${ }^{55}$ Both the bhopas and the Hindu mendicants deployed what were known as jantra-mantra, or spells with miraculous powers.

Hendley also failed to say anything about illnesses that were believed to have a divine origin, which is something spoken about in other reports. For example, writing in 1890, the missionary C.S. Thompson noted that when the rains failed or there was a great deal of sickness in their villages, the Mewar Bhils would take a vow before at the shrine of the local Devi (mother-goddess) that if she brought rain or stopped the sickness they would sacrifice a buffalo to her. When the sacrifice was eventually performed, the Devi was offered the blood, while the meat was sold. Thompson saw this bargaining before the goddess and their selling of the meat as a sign of their practicality in such affairs. ${ }^{56}$

It is clear from the descriptions of Hendley and others that the Bhils of this region adopted a number of approaches to healing. They provide, however, merely a catalogue of practices, rather than an analysis that reveals the relationship between them. One influential attempt to understand such healing practices has been provided by the doctor and anthropologist, John Jantzen, who worked in the Congo in the 1960s. Jantzen found that there was much mutual incomprehension between white doctors and their patients as to the nature of disease and its cure. Through his investigation, he found that the local people made a distinction between a 'natural'cum- 'divine' and a 'human' cause of illness. If a disease responded readily to therapy, or was predictable - as when very old people fall sick and die - it was normally seen as 'natural'-cum-'divine'. If a disease was intractable, it might have so it was believed - been caused by human malevolence. Patients and their kin had to decide within which category to place an illness before consulting a specialist. Western medicine was generally considered efficacious in the treatment of 'natural'cum-'divine' illnesses, as were some herbalists. But, if a disease took an unusual or slow course, or if there was conflict within the social group of the sufferer, human causes were suspected. Attempts were then made to resolve conflicts, cast counter spells, and perform rituals of purification. ${ }^{57}$ Using this insight, we might conjecture on the basis of our evidence that the Bhils placed the causes of illness in three categories - the natural, the malign and the divine. If natural, herbal remedies would provide the appropriate cure. If malign, charms, sacrifices or cauterisation provided the first line of defence, with exorcism to discover the human agency as a last resort. If divine, the god or goddess had to be propitiated. We might thus argue that the Bhils would have been willing to try the medicine of the British when the cause was seen as natural, but rejecting it when the cause was believed to be otherwise. ${ }^{58}$

\footnotetext{
${ }^{54}$ Deposition of Bheel Kalia Budo of Deraj of the Mondetta Putta taken before the Attachment Mehta at Mondetta, 14 April 1843. Gujarat State Archives, Vadodara Branch, Baroda Residency, English Department, Serial no 407, Mahikantha, Daftar 83, Vol. 412, MK 13, Vol. 298 for 1843 to 1844.

${ }^{55}$ G.S. Ghurye, Indian Sadhus, Bombay: Popular Prakashan, 1964, 70-71.

56 'The Bhil Mission', Annual Letter of the Rev. C.S. Thompson, Kherwara, 31 January 1890, Intelligencer, 15 NS, 1890, 610-11.

${ }^{57}$ John Janzen, The Quest for Therapy in Lower Zaire, Berkeley: University of California Press, 1978, 8-9.

${ }^{58}$ Terence Ranger has tried in this sort of way to apply Jantzen’s thesis to other parts of Africa. See his article 'Medical Science and Pentecost: The Dilemma of Anglicanism in Africa,' in W.J. Shields (ed.), The Church and Healing, Oxford: Basil Blackwell, 1982, 339.
} 
Such explanatory devices are, in my opinion, of rather limited use. In actual practice, the cause of a disease or, indeed any other misfortune, was by no means transparent, and a range of approaches might be taken to counter it. Herbal cures might provide the first line of defence, with other remedies being applied if the problem continued to be intractable. Also, an attempt might be made to make a 'natural' remedy more efficacious through supernatural means. These sorts of ambiguity were seen in the case already mentioned in which help was sought from a sadhu. The evidence comes from the court testimony of a Bhil whose brother Rupa had been murdered by an official of Pol state. In 1843, Rupa's wife fell ill, and the sadhu, as we have seen, advised him to go to the liquor shop at a nearby village to purchase some liquor, after which he would provide a charm for her cure. Such healers often demanded liquor, which would be brought when the cure was being undertaken through a ritual ceremony in which the charm or spell was both created and bestowed. Some liquor might be used for libations during the ritual, but the healer himself would consume the bulk of it afterwards. In this sense, it might be seen as a form of payment for services rendered. However, in an argument with his eventual killer, Rupa was said by his brother to have described the liquor as 'medicine. ${ }^{59}$ The term can hardy have been used in the modern clinical sense of the term, for liquor - with its consciousnesschanging powers - was seen to have certain supernatural qualities. But also, it could at the same time be seen to provide a fortifying tonic for the sick. In all of this, categories that may be useful as heuristic devices slide into each other in an actual case-narrative.

It was indeed this very slipperiness of categories that perplexed and annoyed doctors from a clinical background. In their eyes, the 'real' cause of a disease was 'natural.' Supernatural explanations lacked any clinical validity, and were thus bogus and furthermore - advanced only to bamboozle and exploit the ignorant.

The arrival of the British with their small hospital at Kherwara introduced a new system of healing for the Bhils, known in the area to this day as Angreji Dawa, or 'English Medicine.' The British believed that once the superiority of this medicine was appreciated, the supposedly 'primitive' beliefs of the Bhils has in regard to health and healing would soon fade away to be replaced with more 'rational' and 'civilised' medical notions. In this they were to be disappointed, for the Bhils continued to believe strongly that many diseases were caused supernaturally. The doctors themselves were moreover often viewed with suspicion, as they were known to carry out surgery, a practice that was frequently seen as having a malign intent. One of the doctors who was working at Kherwara in the early 1880s became so exasperated by his failure to persuade Bhils to submit themselves to the surgical knife, even in minor and easily cured cases, that he resorted to underhand means. He offered financial inducements to get people whom he felt required operations to come to his surgery, whereupon he then carried out the operation without obtaining their formal consent. He believed that the results would speak for themselves. As it was, rumours quickly spread about how the English doctors were violating the bodies, lives, and very

\footnotetext{
${ }^{59}$ Deposition of Bheel Kalia Budo of Deraj of the Mondetta Putta taken before the Attachment Mehta at Mondetta, 14 April 1843. Gujarat State Archives, Vadodara Branch, Baroda Residency, English Department, Serial no 407, Mahikantha, Daftar 83, Vol. 412, MK 13, Vol. 298 for 1843 to 1844.
} 
spiritual being of their Bhil patients, causing a dramatic decline in the numbers attending the clinic. ${ }^{60}$

The missionary C.S. Thompson arrived in the area to work amongst the Bhils soon after this incident, and he found that, as an Englishman, he was viewed with similar suspicion. He had come believing that if he provided medical care, the Bhils would respond more eagerly to the Gospel message. For this purpose he had taken some rudimentary medical training in England before he left for India. As it was, this approach now repelled rather than attracted his would-be audience. He persevered, nonetheless, gradually managing to win confidence for his methods by going out to the Bhils in their villages and offering to treat them for minor complaints on the spot. When it became clear that people were benefiting from his simple remedies, many came forward, and he soon found himself carrying out a thriving practice. ${ }^{61}$

The scene was thus set for a new sort of 'English' doctor, the medical missionary. In the early years of the twentieth century, following the path forged by Thompson, mission dispensaries and a hospital were opened and fully qualified doctors came to practice amongst the Bhils. As converts were gradually gained, the new Christians were required by the missionaries to abandon their older beliefs in the malign supernatural causation of illness and embrace the new 'English medicine' wholeheartedly. The story of the difficulties and in some cases outright opposition that the missionaries encountered in this respect forms the subject of another paper. ${ }^{62}$

\footnotetext{
${ }^{60}$ C.S. Thompson, 'Report on Bheel Mission, Kherwara,' Intelligencer, 7 NS, 1882, 592.

${ }^{61}$ C.S. Thompson, 'Report on Bheel Mission, Kherwara,’ Intelligencer, 7 NS, 1882, 593.

${ }^{62}$ David Hardiman, 'Christian Therapy: Medical Missionaries and the Adivasis of Western India,' in David Hardiman (ed.), Healing Bodies, Saving Souls: Medical Missions in Asia and Africa, Amsterdam: Rodopi Press, 2006.
} 